\title{
Corrigendum: Genome sequencing and analysis of the biomass-degrading fungus Trichoderma reesei (syn. Hypocrea jecorina)
}

Diego Martinez, Randy M Berka, Bernard Henrissat, Markku Saloheimo, Mikko Arvas, Scott E Baker, Jarod Chapman, Olga Chertkov, Pedro M Coutinho, Dan Cullen, Etienne G J Danchin, Igor V Grigoriev, Paul Harris, Melissa Jackson, Christian P Kubicek, Cliff S Han, Isaac Ho, Luis F Larrondo, Alfredo Lopez de Leon, Jon K Magnuson, Sandy Merino, Monica Misra, Beth Nelson, Nicholas Putnam, Barbara Robbertse, Asaf A Salamov, Monika Schmoll, Astrid Terry, Nina Thayer, Ann Westerholm-Parvinen, Conrad L Schoch, Jian Yao, Ravi Barbote, Mary Anne Nelson, Chris Detter, David Bruce, Cheryl R Kuske, Gary Xie, Paul Richardson, Daniel S Rokhsar, Susan M Lucas, ন Edward M Rubin, Nigel Dunn-Coleman, Michael Ward \& Thomas S Brettin

Nat. Biotechnol. 26, 553-560 (2008); published online 4 May 2008; corrected after print 9 October 2008.

In the version of this article initially published, an author's name was misspelled as Barbote. The correct spelling is Barabote. The error has been corrected in the HTML and PDF versions of the article.

\section{Corrigendum: Public biotech 2007—the numbers}

\section{Stacy Lawrence \& Riku Lähteenmäki}

Nat. Biotechnol. 26, 753-762 (2008); published online 8 July 2008; corrected after print 9 October 2008.

In the version of this article initially published, in Table 6, two company names appeared in the incorrect columns. GlaxoSmithKline should be the Acquirer (not the Target) and Reliant should be the Target (not the Acquirer). The error has been corrected in the HTML and PDF versions of the article.

\section{Corrigendum: Predicting PDZ domain-peptide interactions from primary} sequences

Jiunn R Chen, Bryan H Chang, John E Allen, Michael A Stiffler \& Gavin MacBeath

Nat. Biotechnol. 26, 1041-1045 (2008); published online 17 August 2008; corrected after print 9 October 2008

In the version of this article initially published, a negative sign was omitted before the expression $P^{u n i f i e d}(\mathrm{a}, \mathrm{b})$ in the text on page 1043 , col. 1 , line 20 and the color key in Figure 2 was upside down. These errors have been corrected in the HTML and PDF versions of the article. In addition, a sentence was added to the legend of Figure 2 to clarify the significance of positive and negative values of $P^{\text {unified }}(a, b)$. 